\title{
Analisis Tipologi Tanda Sign System Berbentuk Stroberi di Kecamatan Junrejo Kota Batu
}

\author{
Faldi Hendrawan \\ Desain Komunikasi Visual, STMIK ASIA Malang \\ faldikobenasia@gmail.com
}

\begin{abstract}
ABSTRAK
Kota Batu merupakan kota pariwisata yang terdapat di daerah Jawa Timur. Kota Batu merupakan ikon kota wisata dan Agropolitan karena didukung oleh letak geografis di dataran tinggi dan diapit banyak gunung. Pembedaan yang dilakukan oleh pemerintah Kota Batu ini menjadi semakin berkembang, ketika pemerintah Kota Batumemberikanfasilitas media informasi untuk masyarakat. Salah satunya adalah sign system berwujud papan penunjuk nomor rumah berbentuk buah stroberi di Kecamatan Junrejo Kota Batu. Keunikan bentuk Sign system juga tidak mengacu bentuk pendahulunya yang hanya berisi teks atau tulisan angka dengan bingkai kotak sederhana. Di dalam struktur sign system stroberi pemilihan objek bentuk stroberi sebagai nomor identitas rumah mengindikasikan ada pembedaan objek yang menarik untuk dikaji. Perspektif semiotika visual akan lebih mampu membedah struktur tanda yang ada pada sign system stroberi tersebut. Analisis tanda yang diacu menggunakan tradisi Pierce dengan salah satu tipologi tanda ikon indeks dan simbol. Dengan memakai analisi tipologi tanda berdasarkan hubungan tanda dengan objek yang diacu, sehingga pertanyaan berupa latar belakang pemilihan dan seleksi objek terkait tidak dengan identitas yang dapat mewakili Kota Batu baik kondisi wilayah, program pemerintah ataupun apresiasi masyarakatnya.

Kata kunci: Tipologi Tanda, Sign System, Representasi, Identitas, Kecamatan Junrejo, Kota Batu
\end{abstract}

\section{ABSTRACT}

Batu city is a tourism city located in East Java. Batu city is an icon of tourism city and Agropolitan because it is supported by geographical location in plateau and flanked by many mountains. The distinction made by the Batu City's government became more developed, when the Batu City's government provided an information media facility for the community. One of them is a sign system to be information about signboard house number in the form of strawberry fruit in kecamatan Junrejo, Batu City. The uniqueness of the form Sign system also does not refer to the form of its predecessor which contains only text or writing numbers with a simple box frame. Inside the structure of the strawberry sign system the selection of strawberry shape objects as the home identity number indicates that there is an interesting distinction of the object to be studied. Visual semiotics perspective will be better able to dissect the existing sign structure on the strawberry sign system. The sign analysis is referred to using the Pierce tradition with one of the typology of iconic, index and symbols. Using the analysis of typology of signs based on the sign connection with the object referred, so the question of background selection and object selection related not with identity that can represent the city of Batu either the condition of the region, government program or community appreciation. Keywords:Sign Typology, Sign System, Representation, Identity, Kecamatan Junrejo, Batu City.

\section{PENDAHULUAN}

Kota Batu merupakan kota pariwisata yang terdapat di daerahJawa Timur. Kota batu merupakan ikonkotawisata dan kota Agropolitan karena didukung oleh letak geografis di dataran tinggi dan diapit banyak gunung. Kota Batu sejak masa kolonial Belanda sudah mensejajarkan wilayah Batu dengan sebuah negara di Eropa yaitu Switzerland dan memberikan predikat sebagai De Klein Switzerland atau Swiss kecil di Pulau Jawa. Kondisi alam yang berbukit dengan tanah yang subur tersebut juga melatar belakangi sebagian besar masyarakat kota Batu memusatkan aktivitas keseharian mereka yang terpusat pada pengelolaan alam. (Firman, 2017). Sebagian masyarakat memfokuskan pekerjaan mereka pada sektor pertanian dan perkebunan. Ketergantungan masyarakat Batu yang sebagian besar pada kondisi alam ini juga menjadi tolak ukur visi Pemerintah kota 
Batu tahun 2012-2017 menjadi sentra pertanian organik berbasis kepariwisataan internasional serta salah satu misi dalam mengembangkan pertanian organik dan perdagangan hasil pertanian organik. (http://website. batukota. go. id)

Pengembangan daerah yang terpusat pada kekayaan sumber daya alam dan aktivitas masyarakat di wilayah pertanian dan perkebunan menjadi agenda perubahan Pemerintahan Kota Batu yang mulai terpisah dari Kabupaten Malang sejak tahun 2001, akibatnya fasilitas yang mendukung aktivitas masyarakat juga ikut dikembangkan. Pembedaan yang dilakukan oleh pemerintah Kota Batu ini menjadi semakin kuat ketika semakin hari pemerintah mencoba untuk menambah sarana pendukung atau fasilitas untuk masyarakat. Salah satunya adalah sign system berwujud papan penunjuk nomor rumah berbentuk buah stroberi. Media penunjuk tersebut dirasakan cukup berhasil dirasakan oleh masyarakat batudi kelurahan Pendem dan Dadaprejo, kecamatan Junrejo.

Sign system berwujud desain grafis lingkungan saat ini menjadi trend komunikasi visual yang cukup efektif menginformasikan pesan secara langsung kepada masyarakat. Pemilihan media grafis dimungkinkan lebih mempermudah komunikasi jika memanfaatkan daya dukung gambar. Gambar stroberi dimanfaatkan menjadi simbol yang diyakini masyarakat batu cukup berarti bagi keberadaan mereka. Upaya memanfaatkan simbolsimbol visual berangkat dari kenyataan bahwa bahasa visual memiliki karakteristik yang khas, dan menimbulkan efek tertentu yang berbeda dengan bahasa verbal. Hal inilah yang menjadi latar belakang pembuatan sign system bergambar stroberi ini menjadilebih menarik, modern dan representasional dibandingkan sign system dengan tulisan verbal yang terlihat kaku dan kuno. Sign system berbentuk stroberi dibagikan secara gratis melalui Ketua Rukun Warga atau Rukun Tetangga bagi yang memiliki Kartu Tanda Penduduk di kota Batu, khususnya yang bertempat tinggal di wilayah kecamatan Junrejo.

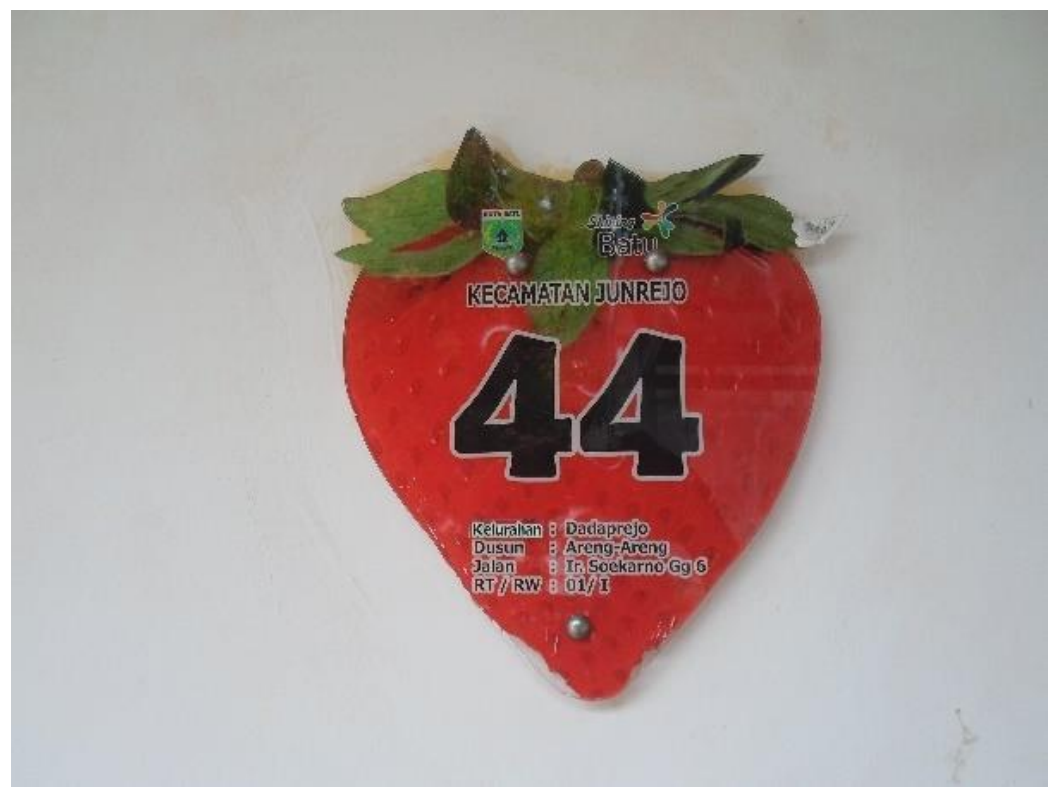

Gambar 1. Tampilan sign system berbentuk stroberi

Grafis kota berupa papan penunjuk tersebut dibuat dari bahan akrilik yang dicetak warna. Dari segi bahan papan penunjuk terbuat dari material yang cukup kuat mengindikasikan bahwa pemerintah Kota Batu memperhatikanhal kecil secara serius, meskipun terlihat hanya lempengan berbentuk gambar stroberi. Jika diperhatikan sebelum munculnya papan penunjuk rumah sebenarnya pemerintah Kota Batu sudah kerap kali 
menerapkan sign system seperti bak sampah dan lampu kota di tepi jalan kota batu berwujud buah apel. Pembagian fasilitas yang digaakkan pemerintah adalah sebuah program wajib yang lebih bersifat aturan mengenai pemasangan identitas tempat tinggal dan berfungsi untuk mempermudah informasi terkait pendataan sebuah wilayah. Peraturan yang berlaku di kecamatan Junrejo salah satunya memasang sign system berbentuk stroberi. Dalam konteks komunikasi, tanda juga membentuk sebuah kesepakatan dalam mempermudah kehidupan bermasyarakat itu sendiri, tergantung masyarakat masih mempercayainilai dari tanda tersebut. Dari dasar tersebut jika dihubungkan dengan sign systemstroberi masyarakat Kota Batu sebagai interpretan tanda mengapresiasi cara pemerintah Kota Batu merepresentasikan identitas kotanya. Masalahnya adalah seperti apa bentuk pemahaman sign system stroberi terpatri dalam benak masyarakat Kota batu dan merasa mewakili identitas yang sudah sesuai dengan visi pemerintah Kota Batu. Pemerintah Kota batu yang memiliki kewenangan sekaligus kekuasaan untuk memilih secara terencana, terukur dan selektif bagaimana tanda visual atas identitas kotanya bisa dirasakan semua warganya, salah satunya dengan sign system tersebut. Persoalan yang sepertinya akan muncul sign system stroberi sebagai jargon visual mampu menerangkan sekaligus mewakili keberadaan masyarakat kota Batu yang lebih heterogen dan majemuk menuju kawasan wisata perkotaan seperti saat ini ataukah hanya menunjukkan aspek fungsional hanya sebagai tanda penjelas nomor rumah.

Dari pendapat tersebut dapat diambil pertanyaan penelitian sampai sejauh mana struktur atau bentuk visual sign system stroberi sebagai tanda visual identitas Kota Batu. Dari visualisasi bentuk sroberi tersebut kemudian diterjemahkan oleh masyarakat Kota batu sebagi praktik yang dimaknai sesuai dengan cita-cita atau visi kota Batu dimasa mendatang. Seperti halnya budaya yang merupakan situs produksi makna dan mengekspresikan identitasnya. Makna akan selalu muncul di dalam dan melalui relasi sosial diantara orang-orang, kelompok, kelas, institusi, sruktur atau benda. Sehubungan dengan produksi makna atas sign system stroberi maka tujuan penting dari penelitian ini adalah mengetahui secara mendalam bagaimana struktur visual dari sign system stroberi dan sehingga menjadipraktik sosial sebagai situs makna dan interpretasi bagi masyarakatnya.

Dalam berurusan dengan dengan praktik makna, budaya yang tercermin dari sirkulasi sign system stroberi sepertinya akan melebar luas pada persoalan ekonomi, hukum dan pemerintahan. Jika melihat definisi budaya yang dijelaskan oleh Thwaites dkk (2002:1-3) adalah kumpulan praktik sosial yang melaluinya makna diproduksi, disirkulasikan, dan dipertukarkan. Budaya bukanlah proses terpadu tunggal, melainkan sekumpulan praktik. Seperti halnya makna itu bermigrasi dari satu konteks ke konteks lainnya, kadang-kadang berhenti sangat jauh dari tempat makna itu dimulai, makna selalu berpindah-pindah, terbelokkan, diolah kembali dan dipertukarkan. Seperti sign system stroberi bagaimanakah fungsi keberadaan dari sign systemdirasakan bermanfaat dan bernilai lebih bagi kehidupan bermasyarakat di Kota Batu.

Sebuah masalah penelitian yang berangkat dari pernyataan yang berkaitan dengan fenomena produk budaya maka akan dijawab dengan menggunakan perangkat dari tradis kualitatif. Endraswara dalam bukunya Metodologi Penelitian Kebudayaan (2006:14-15) menjelaskan metode kualitafif lebih cenderung memfokuskan diri pada pengamatan yang mengandalkan kekuatan indera peneliti untuk merefleksikan fenomena budaya. Fenomena budaya memang memiliki kekhususan. Disamping itu fenomena budaya biasanya juga berupa kasus kasus unik dan pada tradisi kualitatif peneliti dalam pengumpulan data lebih fleksibel dan reflektif tetapi tetap dapat mengambil jarak. Pengumpulan data dalam 
penelitian ini menggunakan observasi partisipan dan wawancara. Data primer berorientasi pada hasil observasi lapangan dan wawancara, sedangkan data sekunder berasal dari sumber dokumentasi dan studi kepustakaan. Observasi yang dilakukan untuk dapat mengumpulkan data valid ditempuh melalui proses observasi lapangan, dilengkapi kamera foto dan buku catatan. Pengumpulan data dengan teknik observasi dimungkinkan mampu menjawab bagaimana keterkaitan kehidupan sosial yang ada di masyarakat Kota Batu ikut menentukan tanda visual didistribusikan untuk masyarakat luas. Pengumpulan data menggunakan wawancara digunakan untuk memperoleh penafsiran makna dari interpretan dan juga sudah sesuaikan kebijakan pemerintah kota batu atas fasilitas yang dibagikan berupa sign system tersebut. Seperti yang pernah dikemukakan oleh Simatupang (2013:94) wawancara bukan persoalan keterampilan dan mengajukan pertanyaan tetapi kegiatan mendengarkan omongan orang dan meresponnya untuk menggali informasi selengkapnya.

Teori utama yang digunakan untuk menjawab struktur ataupun bentuk sign sistem stroberi dengan menggunakan pembagian jenis tanda dari Semiotika Visual. Menurut Budiman (2011: 9)dalam bukunya semiotika visual pada dasarnya merupakan salah sebuah biudang studi yang secara khusus menaruh minat pada penyelidikan terhadap segala jenis makna yang disampaikan melelui indra lihatan (visual senses). Apabila kita konsisten mengikuti pengertian ini maka semiotika visual tidak laggi terbatas pada pengkajian seni rupa(seni lukis, patung dan seterusnya) dan arsitektur semata-mata, melainkan juga segala mcam tanda visual yang kerap kali atau biasanya dianggap bukan karya seni. Dari hal tersebut dirasakan sesuai jika teori ini dihubungkan dengan objek penelitian berupa papan penunjuk yang dibagikan secara massal kepada masyarakat di kecamatan Junrejo.

Semiotika visual yang dirujuk untuk menganalisis tanda terutama memanfaatkan tipologi tanda Pierce. Budiman tanda yang digunakan dalamPierce terutama menjelaskan jenis tanda berdasarkan hubungan antara penanda dan petandanya berlandaskan definisi dan tipologinya (Pierce, 1986:5). Dalam memahami struktur sebuah wujud desain tentunya berkaitan erat dengan unsur-unsur pembentuk desain dan isinya. Secara umum mulai unsur tekstualnya terdiri seperti warna, gambar, bahan, material, dan konteks atau nilai yang membangun unsur kesatuan sign system tersebut. Kedua unsur ini akan dibahas secara tumpang tindih dan saling terkait antar pembentuknya dan isinya. Budiman juga menambahi bahwa Semiotika Pierce memandang dari sisi hubungan representasemen dengan objeknya yakni hubungan "menggantikan" atau the standing for relation, tandatanda diklasifikasikan menjadi ikon (icon), indeks (index) dan simbol (symbol). Pierce menganggap pembagian tanda yang paling fundamental (2011:78), sehingga untuk penentuan teori yang paling tepat dengan menggunakan pola representamen dan objek yang diacu oleh papan penunjuk rumah berbentuk stroberi.

\section{PEMBAHASAN}

Kesepakatan nilai tanda dalam sebuah masyarakat membentuk cara, perilaku kesehariannya danhampir dipastikan terkait dengan pola kehidupan sosial budayanya. Fiske (2012:105) menyebutkan dalam bukunya Pengantar Ilmu Komunikasibahwa hampir semua aspek di dalam kehidupan sosial, baik konvensional maupun yang dikontrol oleh berbagai aturan yang telah disetujui oleh anggota masyarakat, dapat disebut kondisi yang 'dikodekan'. Kode yang dirumuskan oleh Danesi (2004:27) berarti sistem tanda (verbal, visual, gestural, dan lain-lain) yang mempunyai sifat tertentu dan karenanya dapat digunakan berulang kali untuk mengodifikasi dan mendekodifikasi teks dan pesannya. Kode sama halnya seperti bahasa sebagai sebuah system yang menyediakan struktur dan menspesifikasikan relasi antar tanda untuk tujuan membuat pesan. Kode mungkin bisa menjadi sumber kreativitas yang tiada habisnya dari pola-pola kehidupan bermasyarakat 
tersebut menjadi identitas sekaligus modal simbolis untuk mengidentifikasikan karakteristik daerahnya. Strategi inilah yang dipilih pemerintah untuk menyesuaikan pola kehidupan masyarakatnya yang mayoritas adalah petani. Dari kehidupan utama pertanian ini juga membutuhkan jargon visual yang tepat yang dipilihkan oleh sebagai masyarakat dan pemerintah Kota Batu yaitu buah stroberi. Kalau dikaji lebih lanjut maka objek gambar stroberi yang dipilih oleh pemerintah kota batu semestinya mempunyai nilai yang masih dimaknai oleh masyarakatnya.

Referensi kode papan penunjuk nomor rumah mengacu bentuk pendahulu sebelum bentuk stroberi atau struktur utama sign system yang berlaku di Indonesia secara umum. Secara umum sign systemberupa nomor rumah hanya berisi teks atau tulisan angka dan verbal penunjuk detail wilayah tempat tinggal. Di dalam struktur sign system stroberi peletakan ukuran gambar yang berhias bentuk stroberi mengindikasikan ada pembedaan wujud yang sebelumnya pernah ada. Sebelum ada papan penunjuk rumah berbentuk stroberi itupun wujud masih dinilai kaku dan hanya mencantumkan informasi tulisan saja. Hal tersebut direspon Rina dewi sebagai narasumber yang bertempat tinggal di kecamatan Junrejo menyepakati perubahan plakat yang dijadikan sign system lebih bagus bentuk atau desainnya daripada periode yang dibagikan beberapa tahun lalu. Dari bentuk yang lebih besar ukurannya juga menentukan tingkat keterbacaan yang lebih baik. Rina Dewi juga berpendapat ada perbedaan yang signifikan pemerintah sekarang mulai menyeragamkan beberapa aspek visual sebagai agenda perubahan kota yang semakin dikenal dan populer di mata wisatawan.

Jika memandang perspektif ilmu desain komunikasi visual sebuah karya, produk, manusia sudah seharusnya mampu mengatasi pemecahan masalah komunikasi visual. Keberadaan sign system produk sign system ini pasti berkaitan erat dengan cakupan area desain grafis yang lekat dengan penekanan komposisi atau peletakan layout atau gambar. Keberadaan sign system stroberi sebagai produk desain grafis melibatkan perpaduan dan perkawinan antara nirmana dan tipografi. Tinarbuko (2015:45) memperkuat pernyataan bahwa keduanya seperti pasangan kinasih yang tidak bisa dipisahkan oleh ruang dan waktu. Dalam hubungannyanya desain grafis, tipografi dan nirmana adalah elemen penting yang sangat diperlukan guna mendukung proses penyampaian pesan verbal maupun visual.

Wujud sign system sebelumnya juga masih didominasiangka dan tulisan warna hitam atau biruwarna fontnya dengan latar kontras berwarna putih. Penataan layoutnya masih terkesan sederhana dengan informasi nomor dan identitas rumah didalam bigkai garis kotak. Tentu sudah berbeda jika dibandingkan dengan struktur bentuk yang merupakan hasil komposisi antara font angka bergaya dekoratif yang berada di tengah gambar stroberi. ukuran anatomi huruf dan peletakan di posisi tengah memunculkan kesesimbangan yang berkesan simetris dan terpusat. Pewarnaan angka berwarna hitam dengan outline putih cukup menambah unsur kontras yang cukup jauh dengan warna merah stroberi yang menjadi latar belakangnya. Dari keberadaan angka tersebut kejelasan yang ditimbulkan dari sign system terbaru cukup terbaca dengan baik, apabila menilai dari prinsip menerapkan tipografi yang baik adalah ada unsure readibility makasign system terbaca dengan baik pula. Keberadaan sign system masih tampak jelas jika sudah tertempel di dinding rumah dan dilihat dari jarak amatan di luar pagar rumah. Jika disimulasikan ketika sesorang mencari nomor rumah sesorang sejauh lima meter dari halam luar pagar masih terlihat tampak jelas. Penambahan informasi diatas dan dibawah nomor berupa logo kota batu, kalimat jargon dan informasi alamat kelurahan, dusun, Rukun Tetangga dan Rukun Warga melengkapi informasi sebuah petunjuk wilayah rumah tersebut. 
Sign system merupakan salah satu produk desain grafis yang menunjukkan fungsi penunjuk sesuatu informasi yang lebih diutamakan oleh penataan dan perpaduan objek gambar dan unsur tipografi. Desain grafis secara umum diartikan Tinarbuko sebagai salah satu cakupan ilmu dari desain komunikasi visual yang mempelajari konteks tata letak dan komposisi (2015:6). Sign system stroberi hadir dalam bentuk gambar dan di display di sebagian rumah besar warga kota Batu. Wujud gambardengan informasi kependudukan ini berfungsi untuk memenuhi kebutuhan masyarakat sebagai identitas tempat tinggal. Gambar yang dicetak pada bagian dalam dari bahan akrilik tersebut menggunakan objek utama berupa foto stroberi yang menjadi faktor penarik utama sebuah produk. Penambahan informasi nomor dan alamat wilayah memilih beberapa paduan font jenis yang berbeda. Dalam perspektif semiotika Pierce gambar stroberi yang terdapat pada sign system termasuk dalam jenis ikon, jika dipandang dari representamen dengan objeknya. Budiman menerjemahkan konsep ikon sebagai tanda yang didasarkan atas keserupaan atau kemiripan atau resemblance diantara representamen dan objeknya, entah objek tersebut betul-betul eksis ataupun tidak, akan tetapi sesungguhnya ikon tidak semata-mata mencakup citra "realistis" pada lukisan atau foto saja melainkan juga ekspresi-ekspresi semacam grafik grafik, skema, skema, peta geografis, persamaan matematis, bahkan metafora (2011: 78).

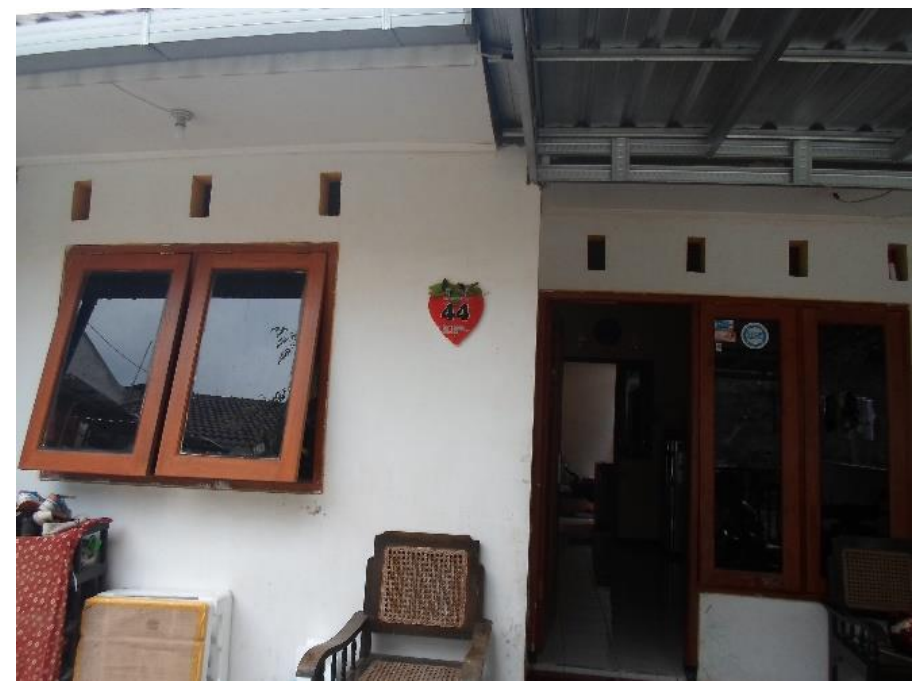

Gambar 2. Tampilan sign system dari jarak 2 meter

Aspek visualitas yang terwujud dari material dan fisik utama sign system stroberi didasarkan dari gambar foto umumnya memiliki format bitmap. Gambar stoberi bercorak realisme sebagai objek utama stroberi dengan beberapa lembar kelopak daun berwarna hijau sudah mengidentifikasi kemiripan bentuh buah stroberi secara fisik. Pewarnaan yang dihasilkan dari percetakan ke bagian dalam material akrilik tersebut juga hasil editing foto yang secara jelas mengidentifikasi kedetailan hasil warna, tekstur, bayangan maupun aspek dimensi dari buah stoberi. Objek stroberi dapat dikenali secara jelas sebagai tanda ikonik yang menggambarkan objek buah berukuran kecil, berwarna merah berbintik hitam yang ditanam di daerah dataran tinggi. Yang membedakan hanya ukuran sign system tersebut dengan panjang sekitar $30 \mathrm{~cm}$ dengan lebar $20 \mathrm{~cm}$ sehingga terkesan lebih besar dari ukuran buah stroberi secara fisik bisa dimakan. Keterlibatan pemilihan ukuran dari aspek fungsional juga disesuaikan untuk bisa dilihat oleh seseorang sebagai identitas.

Beberapa informasi selain bentuk gambar stroberi sebagai media penggiring perhatian ada juga beberapa informasi yang menjadi kesatuan penunjuknya berupa nomor 
angka rumah di tengah, logo kota Batu, slogan kota Batu, dan lokasi kecamatan kelurahan, dusun, alamat dan RT juga RW. Pemakaian font berwujud angka di bagian tengah berwarna hitam yang jelas terbaca dari jarak amatan normal tersebut termasuk dalam kategori tanda yang bersifat indeksikal, karena angka menunjukkan tanda yang bersifat sekuensial dari urutan nomor rumah. Penunjuk lokasi wilayah yang tervisualisasikan dalam font bergaya kelurahan, dusun alamat dan RT atau RW juga dikenal sebagai indeks. Keseluruhan tanda tersebut dikategorikan sebagai tanda visual karena menunjukkan secara eksistensial tanda tersebut berkaitan dengan objek yang lain secara zonasi. Angka penomoran rumah yang tertulis di papan akrilik tersebut dapat dibaca ketika secara eksistensial mengamati urutan dari zona rumah di sebuah lingkungan. Hal tersebut didasarkan pada pendapat Pierce (1986:8) menjelaskan bahwa indeks merupakan tanda yang memilki keterikatan fenomenal atau eksistensial diantara representamen dan objeknya. Di dalam indeks hubungan antar tanda dan objeknya bersifat konkret, aktual, dan biasanya melalui suatu cara yang sekuensial atau kausal. Secara teoritik pemakaian teori tipologi tanda font yang bersifat indeksikal tersebut memiliki kelemahan dari sisi faktualnya karena informasi tidak akan terbaca dari jarak lebih satu meter. Seseorang yang membutuhkan informasi tersebut akan menganggap informasi tersebut tidak efektif dicantumkan. Tidak efektifnya penataan layout juga tampak pada peletakan logo kota Batu beserta jargon berupa Shining Batu dengan latar belakang dari tampak daun stroberi. Dari tingkat keterbacaan (readibility) dan kejelasan (legibility) yang sudah menjadi syarat utama penunjuk identitas tidak terakomasi dengan baik.

Bentuk wujud angka, tulisan wujud secara bentuk juga termasuk salah satu bentuk tanda simbol. Sama halnya logo kota Batu dan slogan kota batu merupakan bentuk simbol. Simbol merupakan jenis tanda yang bersifat arbriter atau konvensional. Tanda-tanda kebahasaan pada umumnya adalah simbol-simbol. Simbol merupakan tanda yang berdasarkan konvensi, peraturan, atau perjanjian yang disepakati bersama. Simbol baru dapat dipahami jika sesorang sudah mengerti arti yang telah disepakati sebelumnnya. Kesepakatan bentuk yang dipilih pemerintah untuk menjadi sebuah identitas wilayahnya juga merujuk pada konteks yang lebih luas, bukan hanya konsep kemiripan bentuknya saja. Sumber acuan masyarakat untuk menginterpretasikan makna stroberi ternyata menyangkut pada kedekatan masyarakat pada sumber alam yang menjadi visi pemerintah Kota Batu.

Rina dewi sebagai salah satu penduduk di kecamatan Junrejo mengungkapkan komentar pada sisi bentuk desain dan tingkat keterbacaan informasinya. Menurutnya dari tingkat keterbacaan informasi merasakan ketidak efektifan, namun dari sisi desain bentuk sudah menunjukkan kemenarikan. Menurutnya tingkat menariknya terlihat dari objek yang berbentuk stroberi, karena pembagian sign system sebelumnya hanya berwujud tulisan dengan informasi saja. Pada beberapa tahun sebelumnya pembagian salah satu sarana informasi juga sudah dianggap merata dan mendapat partisipasi aktif dari sebagian masyarakat diseluruh Rukun Tetangga. Ketua Rukun Tetangga di daerah Rina Dewi juga sempat memantau dan mengawasi pemasangan sign system tersebut. Disamping itu Rina Dewijuga menjelaskan keseragaman itu juga didasarkan pada keberhasilan kota Batu menjadi kota wisata yang semakin memperindah tata kotanya dari sisi visual. Narasumber juga menjelaskan bahwa sudah menjadi kewajiban warga kota batu Batu yang mendapatkan fasilitas sign systemtersebut untuk wajib ditempel di dinding rumah masingmasing. Selama proses observasi yang dilakukan selama beberapa bulan ternyata masih ditemukanbeberapa warga warga di kecamatan Junrejo tidak mematuhi peraturan untuk memasang sign system tersebut. Salah satu contoh di kelurahan Dadaprejo juga ada beberapa yang belum memasang sign system tersebut. 


\section{KESIMPULAN}

Sign system merupakan salah satu media komunikasi yang sangat penting untuk menyampaikan informasi. Salah satunya sebagai penunjuk identitas tempat tinggal seseorang di sebuah wilayah. Pada umunya sebagian besar sign system yang menunjukkan identitas di sebuah daerah dengan tampilan informasi berupa tulisan huruf dan angka, namun berbeda dengan sign system yang terdapat Kelurahan Pendem dan Dadaprejo, Kecamatan Junrejo, Kota Batu dengan bentuk buah stroberi. Secara visual bentuk buah stroberi dapat menunjukkan identitas kota batu yang selaras dengan visinya menjadi sentra pertanian organik berbasis kepariwisataan internasional. Dalam teori semiotika bahwa konteks kehadiran sebuah objek eksis atau tidak akan mengacu pada dimana kode itu dibuat. Latar belakang pencaharian ataupun kondisi alam berdampak dapat menjadi acuan aspek visualitas sebuah tanda dipilih. Pemilihan buah stroberi juga tidak terlepas dari salah satu produk pertanian yang lekat dengan daerah dataran tinggi seperti Kota Batu. Perspektif semiotika dengan tipologi tanda ikon, indeks dan simbol menunjukkan bahwa sign system stroberi diklasifikasikan sebagai ikon dengan media cetak atau printing. Material bahan lempengan berbahan mika akrilik dengan bentuk Stroberi menunjukkan pemilihan bahan selektif karena bahan cukup kuiat ditaruh di luar ruangan. Aspek fungsionalitas dari tingkat keterbacaan dapat dikatakan sudah memenuhi kejelasan yang tinggi karena jarak tiga sampai lima meter dari halaman rumah informasi nomor dapat terlihat jelas, meskipun hanya angka nomor rumah. Pertimbangan aspek visualitas dan fungsionalitas sign system stroberi yang terpadu cukup tepat sebagai media informasi dapat menunjukkan bahwa Pemerintah Kota Batu cukup selektif dalam pelayanan salah satu fasilitas masyarakatnya.

\section{DAFTAR PUSTAKA}

Budiman, Kris. 2011. Semiotika Visual, Konsep, Isu, dan Problem Ikonisitas. Yogyakarta: Jalasutra

Danesi, Marcel. 2004. Pesan, Tanda, dan Makna. Buku Teks Dasar Mengenai Semiotika dan Teori Komunikasi (Terj. ). Yogyakarta: Jalasutra.

Endraswara, Suwardi. 2006. Metodologi Penelitian Kebudayaan. Yogyakarta: Gadjah Mada University Press.

Firman, Tony. 2006. Swiss kecil itu bernama Batu. (Online) diunduh pada tanggal 20 Agustus 2017.

Fiske, John. 2016. Pengantar Ilmu Komunikasi. Jakarta: Rajawali Press.

Pemerintah Kota Batu. 2005. Visi dan Misi. (Online). diunduh pada 20 Agustus 2017.

Pierce, Charles S. 1986. Logic as semiotics: The Theory Of Sign, dalam Robert E. Innis (ed) Semiotic: An Introductory Reader. London: Hutchinson.

Simatupang, Lono. 2013. Pergelaran. Sebuah Mozaik Penelitian Seni dan Budaya. Yogyakarta: Jalasutra:

Thwaites, Tony, Llyoid Davis, dan Warmick Mules. 2002. Introduction Cultural and Media Studies. Sebuah Pendekatan Semiotic (terj). Yogyakarta: Jalasutra.

Tinarbuko, Sumbo. 2015. DEKAVE Desain Komunikasi Visual-Penanda Masyarakat Global. Yogyakarta: CAPS ( Center for Academic Publishing Service). 